\title{
MPPT oscillations minimization in PV system by controlling non-linear dynamics in SEPIC DC-DC converter
}

\author{
M. Vaigundamoorthi' ${ }^{1}$, R. Ramesh ${ }^{2}$, V. Vasan Prabhu ${ }^{3}$, K. Arul Kumar ${ }^{4}$ \\ ${ }^{1,4}$ Department of Electrical and Electronics Engineering, Madanapalle Institute of Technology \& Science, India \\ ${ }^{2}$ Department of Electrical and Electronics Engineering, CEG, Anna University, India \\ ${ }^{3}$ Department of Electrical and Electronics Engineering, St. Joseph's College of Engineering, India
}

\begin{tabular}{l} 
Article Info \\
\hline Article history: \\
Received Feb 27, 2019 \\
Revised May 2, 2020 \\
Accepted Jun 17, 2020 \\
\hline Keywords: \\
Adaptive controller \\
Chaos \\
MPPT \\
SEPIC converter \\
Solar PV module \\
\hline
\end{tabular}

\begin{abstract}
Solar PV power generation has achieved rapid growth in developing countries which has many merits such as absence of noise, longer life, no pollution, less time for installation, and ease of grid interface. A maximum power point tracking circuit (MPPT) consists of DC-DC power electronics converters that are used to improve the energy attainment from solar PV array. This paper presents a detailed analysis to control of chaos, a non-linear dynamic in SEPIC DC-DC converter interfaced solar PV system, to minimize the oscillations near to MPP. In SEPIC DC-DC converter, the input inductor current is continuous and capable of sweeping the whole I-V curve of a PV module from open circuit voltage $\left(\mathrm{V}_{\mathrm{oc}}\right)$ to short circuit current $\left(\mathrm{I}_{\mathrm{sc}}\right)$ operating points. To trace the true maximum power point and to nullify the oscillations near to MPP, the yield output voltage needs to ensure period-1 operation.
\end{abstract}

Copyright $\odot 2020$ Institute of Advanced Engineering and Science. All rights reserved.

\section{Corresponding Author:}

M. Vaigundamoorthi,

Department of Electrical and Electronics Engineering,

Madanapalle Institute of Technology \& Science,

Madanapalle, Andhra Pradesh-517325, India.

Email: bacyavaigo2000@gmail.com; drvaigundamoorthim@mits.ac.in

\section{INTRODUCTION}

Solar power is a Green energy sources that employs DC-DC converter to harvest maximum power. The efficiency of the energy conversion process is declined due to climate variable temperature, partial shading, and atmospheric irradiation change and load conditions. The PV current changes with irradiation greatly and the atmospheric temperature affects PV voltage [1-4]. The MPP is detected by Adaptive perturb and observer MPPT algorithm which is embedded in Microcontroller, generate gate pulse which is applied to the DC-DC converter switches [5-8].

The various types of DC-DC converters [9-12] such as buck, boost, buck boost, Cuk and SEPIC are implemented in PV system by considering suitability factors such as cost, efficiency, maximum power flow, ease of drive system, Positive output voltage, system stability and concluded that SEPIC converter is commonly used in PV system to track maximum power from PV panel. Higher order converter such as SEPIC and Cuk are widely used for MPPT charge controller because of their excellent steady state performance, isolation, over current limit protection [13-21]. Quamruzzaman [17] has argued that the PV current with less ripple and improved dynamic response can be achieved by SEPIC converter also proved that high input current ripple content of the converter reduces the average value of current which may leads to wrong true MPP tracking.

Non-linear dynamics in power electronics circuits was put forward in [22-24] undergo sub-harmonics, quasi-periodic oscillations, and chaotic mode of operation. The chaos is experienced in DC-DC converters and its control methods are conducted in power electronics circuits. This abnormal operation would affect converter tracking efficiency since the period -1 operation need to be ensured for MPP tracking in order to minimize oscillations near to MPP. Several studies [25-27] have suggested many control methods that are mitigated to 
supress chaos. Also, The PID controller and sliding mode controllers are also experimented to nullify the effect of chaos in DC-DC converters.

This paper explores that SEPIC DC-DC converter interfaced solar PV system may enter into chaoticaperiodic mode during maximum power tracking process. The analysis and suppression of chaos in a voltage mode-controlled SEPIC converter-based solar PV system has been mitigated and the use of adaptive sliding control method is experimented to nullify the chaos effect and that control has been examined to minimize the oscillations near to MPP.

\section{SEPIC CONVERTER BASED SOLAR PV SYSTEM}

\subsection{System description}

Figure 1 and Figure 2 show the block diagram and hardware setup of sliding mode controlled SEPIC DC-DC converter interfaced solar PV system. The power circuit has an inductors $\mathrm{L}_{1}, \mathrm{~L}_{2}$, capacitors $\mathrm{C}_{1}, \mathrm{C}_{2}$, a Power switch S, a load resistance, a solar PV module (L1235-37Wp) shown in Figure 3.

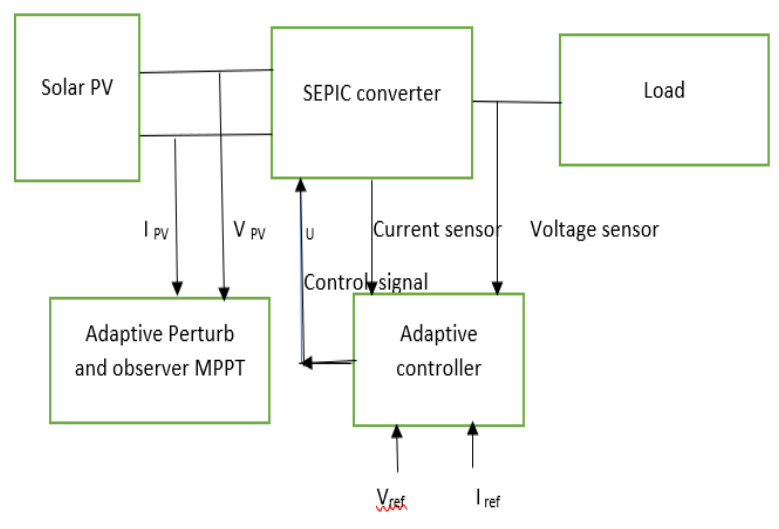

Figure 1. Block diagram

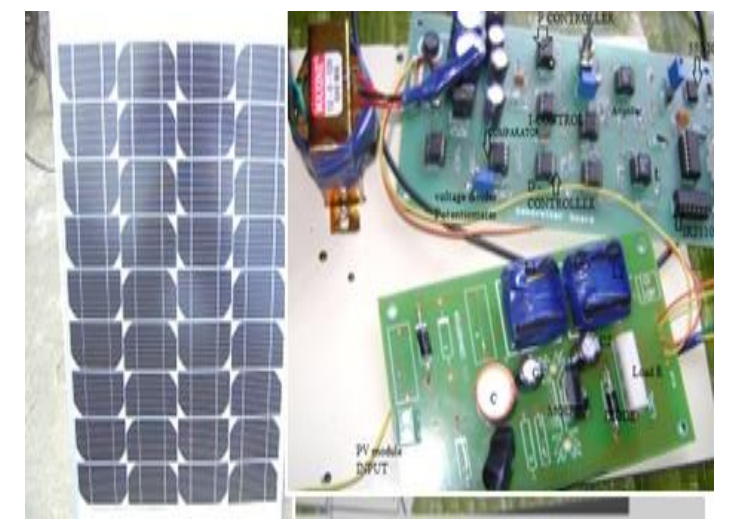

Figure 2. Experimental setup

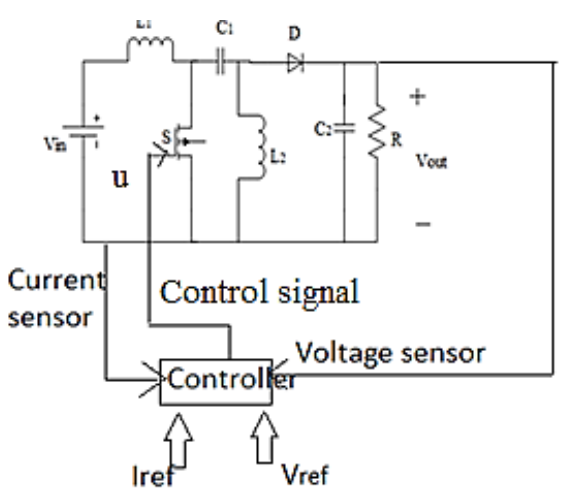

Figure 3. SEPIC DC-DC converter

\subsection{Design of SEPIC converter}

The SEPIC DC-DC converter has advantages such as non-pulsating nature of load current and positive load voltage and has high efficiency than Buck-Boost converter. The positive output voltage is obtained based on the following two modes of operation in one switching period. 1) MOSFET is ON and the diode is not operated. The input inductor, $\mathrm{L}_{1}$, is charged from the PV input voltage. The output inductor $\mathrm{L}_{2}$ finds energy from the first capacitor, and the output capacitor $\mathrm{C}_{2}$ is left to provide the load current. The fact is that both $\mathrm{L}_{1}$ and $\mathrm{L}_{2}$ are disconnected from the load when the switch $\mathrm{S}$, is turned on. In mode 2), The MOSFET is turned off and diode is operated, the input inductor $\mathrm{L}_{1}$ charges the capacitor $\mathrm{C}_{1}$ and also provides current to the load. The second inductor is also connected to the load during this time. The steady state output voltage equation is given by 


$$
\frac{\mathrm{V}_{\mathrm{O}}}{\mathrm{V}_{\mathrm{IN}}}=\frac{\mathrm{D}}{(1-\mathrm{D})}
$$

Also, the steady state current equation is

$$
\frac{\mathrm{I}_{\mathrm{IN}}}{\mathrm{I}_{0}}=\frac{\mathrm{D}}{(1-\mathrm{D})}
$$

The (3) shows the designed value of inductors

$$
\mathrm{L}_{1}=\mathrm{L}_{2}=\mathrm{L}=\frac{\mathrm{V}_{\mathrm{IN}(\mathrm{MIN})} * \mathrm{D}_{\mathrm{MAX}}}{\Delta \mathrm{I}_{\mathrm{L}} * \mathrm{f}_{\mathrm{S}}}
$$

The voltage specifications of capacitor $C_{1}$ is selected as high as input voltage. The ripple voltage of $\mathrm{C}_{1}$ is given by

$$
\Delta \mathrm{V}_{\mathrm{cl}}=\frac{\mathrm{I}(\mathrm{OUT}) * \mathrm{D}_{\mathrm{MAX}}}{\mathrm{C}_{1} * \mathrm{f}_{\mathrm{S}}}
$$

The SEPIC DC-DC converter is designed with inductors $\mathrm{L}_{1}=\mathrm{L}_{2}=500 \mu \mathrm{H}$, Capacitors $\mathrm{C}_{1}=\mathrm{C}_{2}=220 \mu \mathrm{F}$, switching frequency $=25 \mathrm{KHz}$, MOSFET-IRF510, and diode-MUR450 are selected for hardware implementation.

\subsection{L1235-37Wp Solar PV module}

The solar PV output power depends on insolation, atmospheric temperature and type of load characteristic. From the equivalent circuit shown in Figure 4(a), the current and voltage equations are given by (5) and (6) respectively.

$$
\begin{aligned}
& \mathrm{I}_{\mathrm{sc}=} \mathrm{I}_{\mathrm{D}}+\mathrm{I}_{\mathrm{pv}}+\left(\mathrm{V}_{\mathrm{D}} / \mathrm{R}_{\mathrm{p}}\right) \\
& \mathrm{V}_{\mathrm{pv}}=\mathrm{V}_{\mathrm{D}}-\left(\mathrm{I}_{\mathrm{pv}} * \mathrm{R}_{\mathrm{s}}\right)
\end{aligned}
$$

Where diode current is, $\mathrm{I}_{\mathrm{D}=\mathrm{I}_{\mathrm{O}}}+\left(\mathrm{e}^{\left(\mathrm{V}_{\mathrm{D}} / \mathrm{V}_{\mathrm{T}}\right)}-1\right), \mathrm{I}_{\mathrm{sc}}$ is the short circuit current, $\mathrm{V}_{\mathrm{t}}=\mathrm{N}_{\mathrm{s}} \mathrm{KT} / \mathrm{q}$ is the thermal voltage with $\mathrm{N}_{\mathrm{s}}$ cells connected in a series ( $\mathrm{K}$ is the Boltzmann constant, $\mathrm{q}$ is the electron charge and $\mathrm{T}$ is the temperature of the PV cells). Using the equations 5 and 6 , solar PV is modelled and simulated in MATLAB, has V-I charecteristics which is shown in Figure 4(b), The V-I characteristics depend on the conductance of the load. If the conductance value is high, The PV cell behaves like a constant current source region. If conductance value is low, the PV cell acts as a constant volatge source. The parameters of L1235-37W solar PV module which is used for experimental validation are open circuit voltage $\left(\mathrm{V}_{\mathrm{oc}}\right)=21$, Voltage at MPP $\left(\mathrm{V}_{\mathrm{m}}\right)=16.4$, Short circuit current $\left(\mathrm{I}_{\mathrm{sc}}\right)=2.5$ A, Current at MPP $\left(\mathrm{I}_{\mathrm{m}}\right)=2.25 \mathrm{~A}$, Rated power $=37 \mathrm{Wp}$.

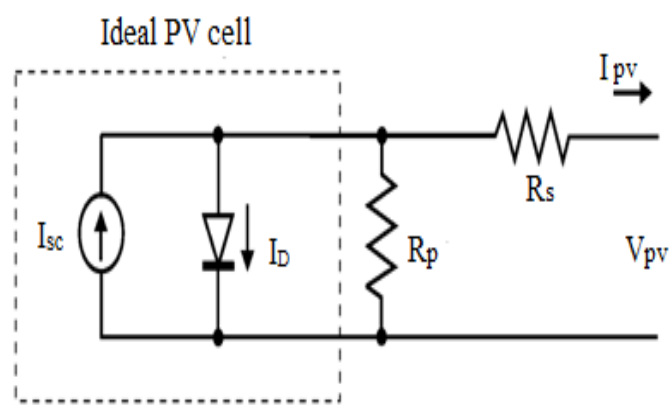

Figure 4. (a) Equivalent circuit of solar PV

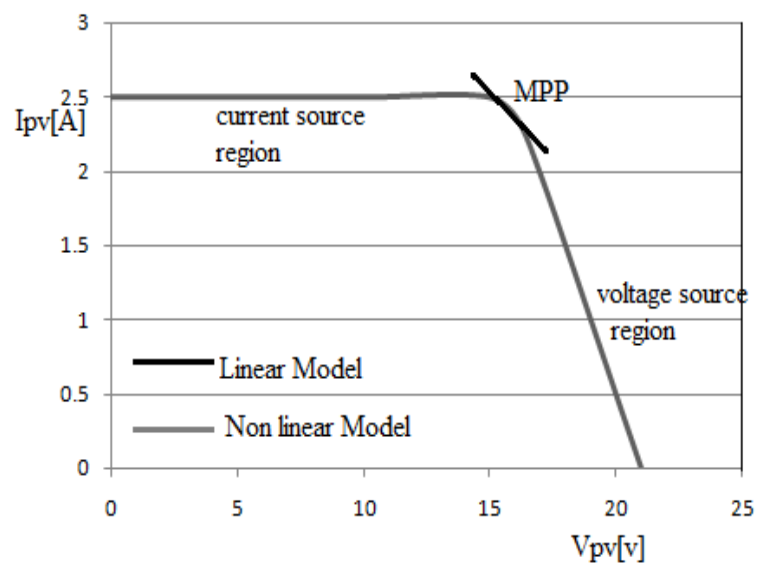

Figure 4. (b) Non-linear V-I characteristics of L1235$37 \mathrm{Wp}$ solar module 


\section{RESULTS AND ANALYSIS}

The SEPIC DC-DC converter interfaced solar PV system is simulated in MATLAB/Simulink shown in Figure 5, which comprises PV electric circuit subsystem (MATLAB model), SEPIC DC-DC converter and a resistive load.

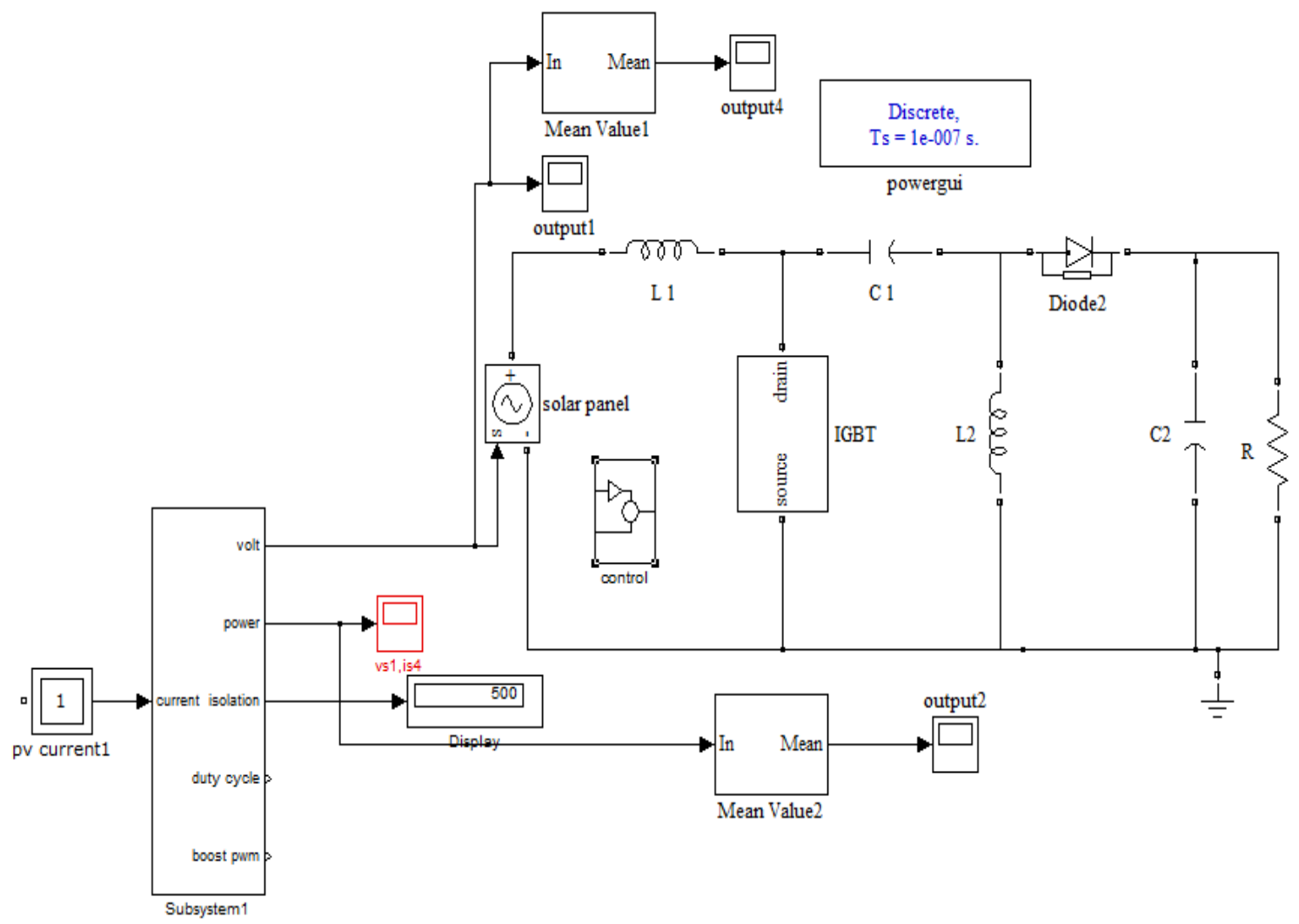

Figure 5. SEPIC converter based adaptive perturb and observer MPPT

The atmospheric constant temperature is considered at $25^{\circ} \mathrm{C}$ and the irradiation level is set as $1000 \mathrm{~W} / \mathrm{m}^{\wedge} 2$ and after $0.01 \mathrm{sec}$, the irradiation $(\mathrm{G})$ is suddenly changed to $500 \mathrm{~W} / \mathrm{m}^{2}$ in computer simulation to test the effectiveness of the adaptive Perturb and Observer algorithm and it was implemented in ATMEGA16 microcontroller. The step size of MPPT algorithm is adjusted which in turn to vary the duty cycle of the switch in order to harvest maximum power which are shown in Figure 6 and Figure 7. The output power is extracted from solar PV module at irradiation of $1000 \mathrm{~W} / \mathrm{m}^{2}$ and $500 \mathrm{~W} / \mathrm{m}^{2}$ are $36.74 \mathrm{~W}$ and $17 \mathrm{~W}$ respectively.

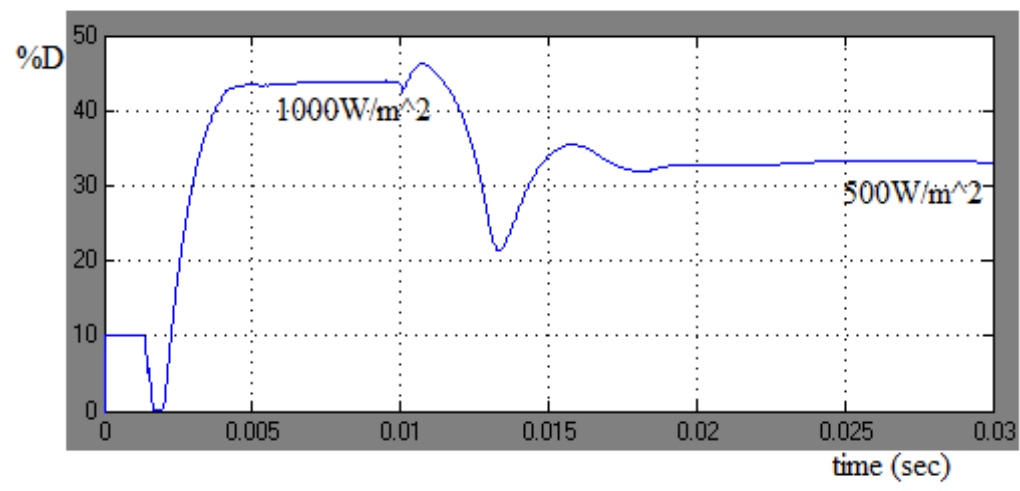

Figure 6. Change in duty cycle for various irradiation level 


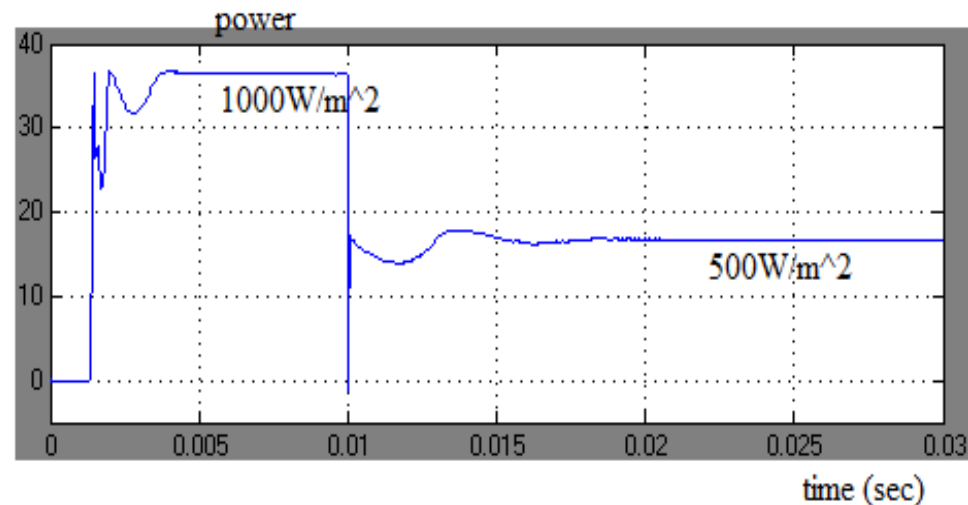

Figure 7. Extracted power for various irradiation level

\subsection{Bifurcation analysis of adaptive controlled SEPIC converter based MPPT}

Under maximum power point tracked condition, to minimize oscillations near to MPP the non-linear dynamic behavior of SEPIC DC-DC converter system is mitigated by adjusting reference voltage $\mathrm{V}_{\text {ref. }}$ The input voltage of the PV fed SEPIC converter is $16.4 \mathrm{~V}$. The ripples of the tracked voltage are examined and found that the fundamental period 1 -waveform is repeated with $\mathrm{V}_{\text {ref }}=5.68 \mathrm{~V}$. At this condition, SEPIC DCDC converter system has stable periodic operating behavior. The input voltage ripple of the period-1 operation under this condition is given in Figure 8.

When the reference voltage $\left(\mathrm{V}_{\text {ref }}\right)$ is adjusted and set as $5.2 \mathrm{~V}$ and the ripples of input is examined. Now, SEPIC DC-DC converter undergo an unstable periodic behaviour. The 1-periodic orbit loses its stable operation, via flip bifurcation it experienced a 2-periodic waveform. The voltage ripple of the period-2 operation is shown in Figure 9.

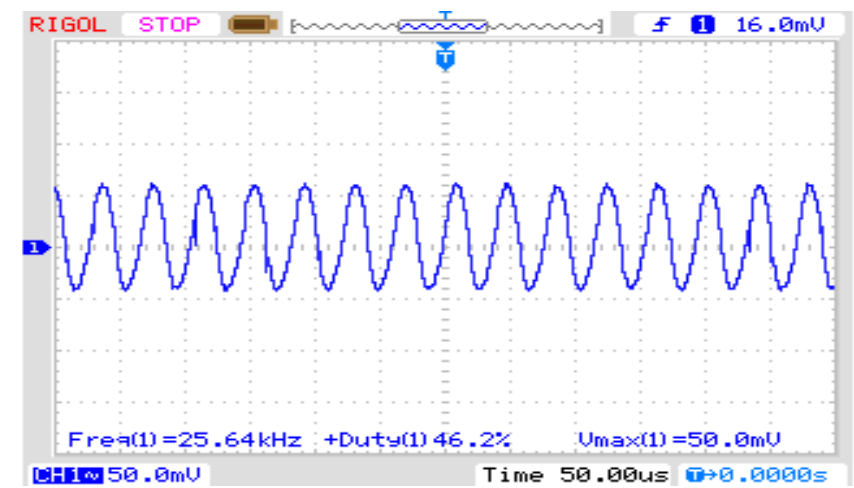

Figure 8. Tracked voltage ripples-period-1 waveform when $V_{\text {ref }}=5.62 \mathrm{~V}$

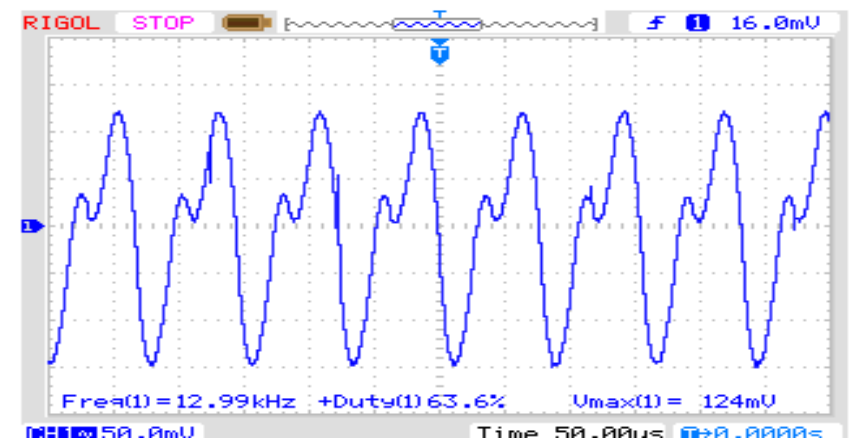

Figure 9. Tracked voltage ripples-period-2 waveform when $\mathrm{V}_{\text {ref }}=5.2 \mathrm{~V}$ 
Further, if $\mathrm{V}_{\text {ref }}$ is varied, the converter operation changed from a stable period-1 operation to an unstable operation. The input voltage ripples of SEPIC converter-has unstable aperiodic behavior. Chaotic waveform is observed for the $\mathrm{V}_{\text {ref }} 4.6 \mathrm{~V}$ as shown in Figure 10. The state change from periodic to aperiodic when Vref is adjusted, be the main cause to near to MPP. The sliding mode controller is designed for SEPIC DC-DC converter by sensing output voltage and input inductor current. The $\mathrm{V}_{\text {ref }}$ is varied from $4.00 \mathrm{~V}$ to $5.6 \mathrm{~V}$ and Iref is set as $0-2 \mathrm{~A}$ and it is proved from Figure 11 that the SEPIC DC-DC converter is operated in period-1 stable region for parameter variation

The chaotic free tracked input voltage from solar PV string is shown in Figure 12. The oscillations are nullified near to MPP by eliminating aperiodic-chaos in solar PV system. The Figure 13 shows the experimental harvested non oscilating power of $36.5 \mathrm{w}$ from solar PV under standard test conditions.

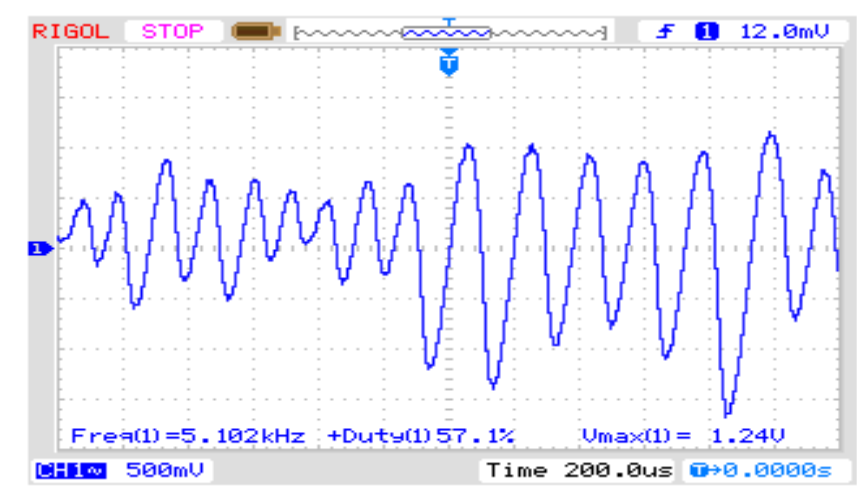

Figure 10. Tracked voltage ripples - aperiodic waveform when $\mathrm{V}_{\text {ref }}=4.6 \mathrm{~V}$

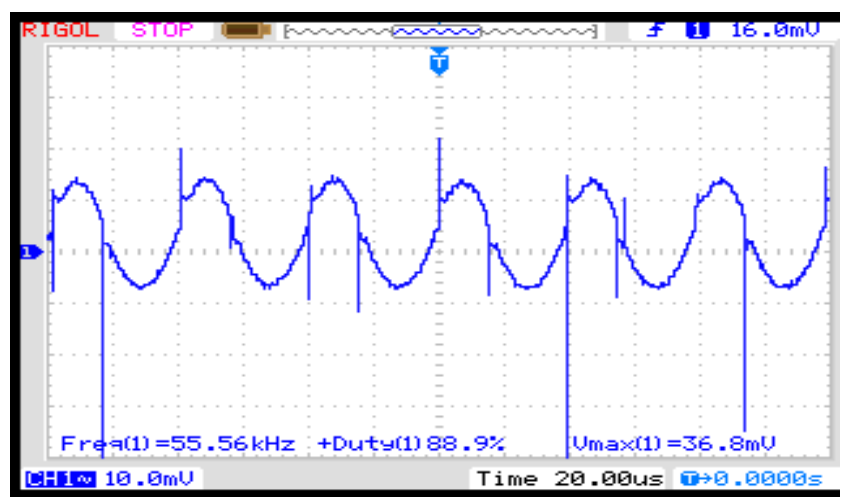

Figure 11. Tracked voltage ripples-period-1 waveform for $3 \mathrm{~V}<\mathrm{V}_{\text {ref }}<5.76 \mathrm{~V}$

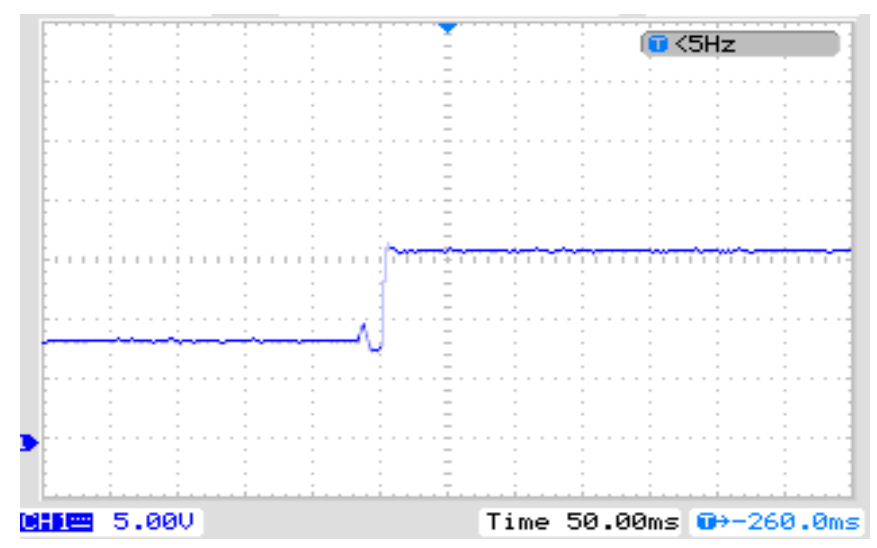

Figure 12. Tracked Input voltage waveform of the converter 


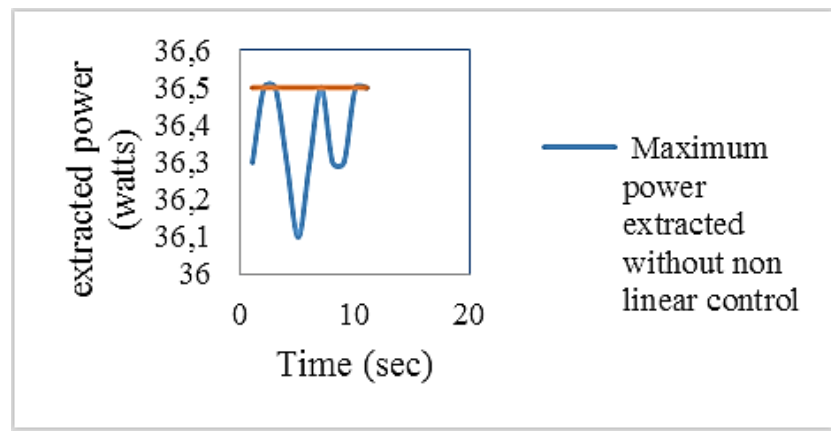

Figure 13. Experimental harvested power from solar PV

\section{CONCLUSION}

The adaptive Perturb and Observer algorithm is implemented and harvested maximum power from solar PV using SEPIC DC-DC converter. To nullify the oscillations near to MPP, aperiodic chaotic behavior of DC-DC converter is exempted experimentally. The sliding mode controller is designed to ensure period 1-operation of the input voltage of SEPIC DC-DC converter.

\section{REFERENCES}

[1] Y. Mahmoud, et al., "A simple approach to modeling and simulation of photovoltaic modules," IEEE Transactions on Sustainable Energy, vol. 3, no. 1, pp. 185-186, 2012.

[2] Y. H. Lim and D. C. Hamil, "Simple Maximum power point Tracker for photovoltaic arrays," Electronics Letters, vol. 36, no. 11, pp. 997-999, 2000.

[3] H. Patel and V. Agarwal, "MATLAB-based modeling to study the effects of partial shading on PV array characteristics," IEEE Transactions on Energy Conversion, vol. 23, no. 1, pp. 302-310, 2008.

[4] S. L. Brunton, et al., "Maximum power point tracking for photovoltaic optimization using ripple-based extremum seeking control," IEEE Transactions on Power Electronics, vol. 25, no. 10, pp. 2531-2540, 2010.

[5] M. Vaigundamoorthi and R. Ramesh, "Implementation and chaotic PWM control of Cuk converter based MPPT for solar PV system," Journal of Electrical Engg, vol. 17, no. 3, pp. 1-8, 2017.

[6] M. Vaigundamoorthi and R. Ramesh, "ZVS-PWM Active clamping modified Cuk converter based MPPT for solar PV modules," European Journal of Scientific Research, vol. 58, no. 3, pp. 305-315, 2011.

[7] M. Vaigundamoorthi and R. Ramesh, "Hardware implementation and steady state analysis of ZVS-PWM Cuk converter based MPP tracking for solar PV module," International Journal of Emerging Electric Power Systems, vol. 13, no. 4, pp. 1-20, 2012.

[8] M. Vaigundamoorthi and R. Ramesh, "Performance analysis of soft controlled DC-DC converter-based MPPT circuits for solar PV module," International Review on Modelling and Simulation, vol. 6, no. 1, pp. 1-8, 2013.

[9] K. K. Tse, et al., "A Comparative Study of Maximum-Power-Point Trackers for Photovoltaic Panels Using Switching-Frequency Modulation Scheme," IEEE transactions on industrial electronics, vol. 51, no. 2, pp. 410-418, 2004.

[10] K. K. Tse, et al., "A Novel Maximum Power Point Tracker for PV Panels Using Switching Frequency Modulation," IEEE transactions on power electronics, vol. 17, no. 6, pp. 980-989, 2002.

[11] H. S. H. Chung, et al., "A Novel Maximum Power Point Tracking Technique for Solar Panels Using a SEPIC or Cuk Converter," IEEE transactions on power electronics, vol. 18, no. 3, pp. 717-724, 2003.

[12] M. Veerachary, "Power Tracking for Nonlinear PV Sources with Coupled Inductor SEPIC Converter," IEEE transactions on aerospace and electronic systems, vol. 41, no. 3, pp. 1019-1028, 2005.

[13] A. R. Kashyap, et al., "Input voltage control of SEPIC for maximum power point tracking," IEEE Power and Energy Conference at Illinois (PECI), pp. 30-35, 2013.

[14] A. Taiwo and J. Oricha, "Modeling, Steady-state Analysis of a SEPIC DC-DC converter based on switching Function and harmonic balance technique," Journal of Power and Energy Engineering, vol. 2, pp. 704-711, 2014.

[15] I. Kim, et al., "Analysis and design of softswitched PWM sepic DC DC converter," Journal of Power Electronics, vol. 10 , no. 5 , pp. 461-467, 2010.

[16] J. Hu, et al., "High frequency resonant SEPIC converter with wide input and output voltage ranges," IEEE Transactions on Power Electronics, vol. 27, no. 1, pp. 189-200, 2012.

[17] M. Quamruzzaman, et al., "Highly efficient maximum power point tracking using DC-DC coupled inductor singleended primary inductance converter for photovoltaic power systems," International Journal of Sustainable Energy, vol. 35, no. 9, pp. 914-932, 2016.

[18] D. Hyun-Lark, "Soft-switching SEPIC converter with ripple-free input current," IEEE Transactions on Power Electronics, vol. 27, no. 6, pp. 2879-2887, 2012. 
[19] M. A. Al-Saffar, et al., "An improved topology of SEPIC converter with reduced output voltage ripple," IEEE Transactions on Power Electronics, vol. 23, no. 5, pp. 2377-2386, 2008.

[20] G. Roger, et al., "A modified SEPIC converter with high static gain for renewable energy applications," IEEE Transaction on Power Electronics, vol. 29, no. 11, pp. 5860-5871, 2014.

[21] N. Mohammad, et al., "Parasitic effects on the performance of DC-DC SEPIC in photovoltaic maximum power point tracking applications," Smart Grid Renew Energy, vol. 4, pp. 113-121, 2013.

[22] M. di Bernardo, et al., "Switchings, Bifurcations, and Chaos in DC/DC Converters," IEEE transactions on circuits and systems-I: fundamental theory and applications, vol. 45, no. 2, pp. 133-141, 1998.

[23] F. Angulo, et al., "Nonlinear and nonsmooth dynamics in a DC-DC buck converter: two experimental set-ups," Nonlinear Dynamics, vol. 46, pp. 239-257, 2006.

[24] P. Kowalczyk, et al., "Two-parameter nonsmooth bifurcations of limit cycles: challenges and open problems," International Journal of Bifurcation and Chaos, vol. 16, no. 3, pp. 601-629, 2006.

[25] X. Zhou, et al., "Chaos Phenomena in dc-dc converter and chaos control," Procedia enginnering, vol. 29, pp. 470-473, 2012.

[26] M. Feki, "Adaptive feedback control of linearizable chaotic systems," Chaos, Solitons and Fractals, vol. 15, pp. 883-890, 2003.

[27] G. Poddar, et al., "Control of chaos in DC-DC converter," IEEE transactions on circuits and systems-I: fundamental theory and applications, vol. 45, no. 6, pp. 672-676, 1998.

\section{BIOGRAPHIES OF AUTHORS}
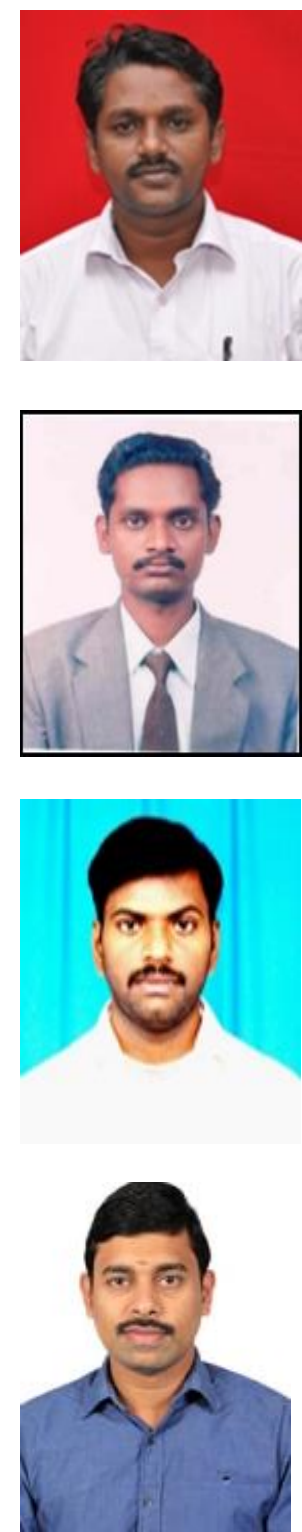

Dr. M. Vaigundamoorthi, working as Professor in the department of Electrical and Electronics Engineering, Madanapalle Institute of Technology and science, Madanapalle, Andhra Pradesh, India. He received his B.E degree in Electrical and Electronics Engineering from Madurai Kamaraj University, Tamilnadu, India in 2002. He received his Master of Engineering degree and Ph.D. in the area of Power electronics and Drives from College of Engineering Guindy (Established 1794- The First engineering college in India), Anna University, Chennai, India in $2007 \& 2013$ respectively. He is having 16 years of teaching experience and has published 7 research articles in reputed international journals. His area of interest include Power Electronics for Renewable Energy System, controller design, Nonlinear dynamics analysis analysis in solar PV system.

Dr. R. Ramesh was born in Tamil Nadu, India. He received his B.E degree in Electrical and Electronics Engineering from University of Madras, Chennai, India in 1999. He received his M.E degree in Power Systems from Annamalai University, Chidambaram, India in 2002. He received Ph.D from College of Engineering Guindy, Anna University, Chennai, India in 2008. Presently he is working as a Professor in the Department of Electrical and Electronics Engineering, College of Engineering Guindy, Anna University, Chennai, India. His research areas are Multi-area Power Systems, Solar PV systems, Power Electronic Converters, Web and Embedded based systems.

Dr. V. Vasan Prabhu, associate professor in the department of Electrical and Electronics Engineering in St. Joseph's College of Engineering, Chennai has 11 years of teaching and research experience. He received his $\mathrm{BE}$ and $\mathrm{ME}$ degrees in Electrical \&Electronics Engineering department from Anna University Chennai. He completed his research work in Switched Reluctance Machine and its control. His area of interest lies in special electrical machines, machine design, drives and control and artificial intelligence.

Dr. K. Arul Kumar has obtained B.E., (Electrical and Electronics) degree from Anna University, Chennai in 2008 and M.Tech (Power Electronics) degree from Vel Tech Dr.RR \& Dr.SR Technical University, Chennai in 2011 and Ph.D. degree in the School of Electrical and Electronic Engineering, VIT University, Vellore in 2017. His current area of research interests are Power electronics in Renewable Energy Systems. He is currently working as Associate Professor in Electrical department in Madanapalle institute of Technology \&Science 